\title{
İskemik ve iskemik olmayan kalp yetersizlikleri arasında sakubitril/valsartan etkinliği yönünden fark var mıdır?
}

\author{
Dr. Mehmet Eren
}

Sağlık Bilimler Üniversitesi, Dr. Siyami Ersek Göğüs Kalp Damar Cerrahisi Eğitim ve Araştırma Hastanesi, Kardiyoloji Kliniği, İstanbul

Kalp yetersizliği (KY), miyokart hasarı yapan bir sebep (miyokard iskemisi veya infarktüsü, infeksiyon, toksinler, genetik anormallikler, hipertansiyon, kapak hastalıkları gibi) sonucu gelişen kardiyak anormallik, egzersiz toleransinda bozulma ve nörohormonal aktivasyonla karekterize bir klinik sendromdur. Tedavisi prensip olarak; semptomların giderilmesine ve nörohormonal aktivasyona yönelik verilecek ortak tedavi ile beraber, altta yatan nedenin tanı ve tedavisine ait girişimlerin de başlatılmasını içerir. KY'nin nedenleri esas olarak iskemik ve iskemik olmayan nedenler olarak gruplandırılır. İskemik olmayan nedenler genel olarak heterojen bir grup olup; başta idiyopatik olmak üzere hipertansif, alkolik, familyal, viral, gebelik ve diğer nadir sebeplerden oluşur. KY'ye etyolojik aç1dan yaklaşmak şu nedenlerden dolayı önemlidir; a) iskemik olanların olmayanlara göre daha kötü prognoza sahip olduğu kabul edilir, ${ }^{[1,2]}$ b) iskemik KY'de yeterli canlı dokunun varlığında koroner revaskülarizasyon dramatik düzelme sağlayabilir, ${ }^{[3]}$ ve c) bazı KY tedavileri etiyolojiye göre farklılıklar gösterebilir (örneğin; tartışmalı da olsa iskemik olmayanlarda kalp içi defibrilatörü daha az etkili iken, kardiyak resenkronizasyon tedavisi daha etkili gibi).$^{[4,5]}$ Ayrıca KY hastalarında görülen nörohormonal aktivasyonun bazı kademelerinde iskemik ve iskemik olmayan etiyolojiye göre farklılıklar vardır. Artan norepinefrin seviyeleri sonucu oluşan miyokarddaki beta-1 reseptör sayısındaki azalma (down regülasyon) iskemik olmayanlarda daha fazla olup ${ }^{[6]}$ bu durum iskemiklerde metoprolol süksinatın ve iskemik olmayanlarda da karvedilolün daha etkin olmasının bir açıklaması olabilir. ${ }^{[7]}$ Ancak ileri KY'de miyokardda anjiyotensin-1 reseptörünün (AT1) down regülasyonu hem iskemik ve hem de iskemik olmayanlarda benzer bir şekilde görülmektedir. ${ }^{[8]}$

KY'de uygulanan tedavilerin sonuçları etyolojiye göre tam değerlendirilmediği gibi bazı tedavilerde de farklılıklar gözlenmektedir (Tablo 1). Düşük ejek- siyon fraksiyonlu KY'de (DEF-KY) yeni tedaviye giren sakubitril/valsartanın KY etyolojisine göre etkinliğinde değişme olup olmadı $\breve{g} 1$ sorusunun cevabı; PARADIGM-HF çalışmasının etyolojiye göre yapılan alt grup analizinin sonuçlarında yer almaktadır. ${ }^{[9]}$ Buna göre PARADIGM-HF çalışmasına alınan 8399 hastanın \%60'1 (n=5036) iskemik gruba ve \%40'1 da $(\mathrm{n}=3363)$ iskemik olmayan gruba dahil edildi. İskemik olmayan hastalardan 1595 'i idiyopatik, 968'i hipertansif ve 800'ü diğerleri olarak sinıflandırıldı. Gruplara dahil edilen hastaların seçimi araştırıcıların kanaatine göre yapıldı. Sakubitril/valsartan tedavisini iskemik grupta 2506 hasta alırken, iskemik olmayan grupta ise 1681 hasta standart tedaviye ilave olarak alıyordu. Diğer hastalara da standart tedavinin üzerine enalapril tedavisi verilmişti. PARADIGM-HF çalışması sakubitril/valsartan-enalapril tedavilerinin karşılaştırılması için randomize edilmişti. ${ }^{[10]} \mathrm{Bu}$ yüzden iskemik-noniskemik grupları; demografik, klinik, KY özellikleri ve tedavileri yönünden benzer değildi. Böylece kabaca yapılan değerlendirmelerde iskemik grupta bütün olaylar daha yüksek gözlendi. Primer bileşik sonucun (kardiyovasküler ölüm veya KY nedenli hastane yatışı) bir yılda 100 hastada görülme oranı iskemik, hipertansif ve idiyopatik gruplarda sirasıyla $12.31,10.41$ ve 10.95 idi. Ancak gruplar arasında farklılıklar gösteren değişkenlere (yaş, cinsiyet, 1rk, yaşanan bölge, sistolik arter basıncı, kalp hızı, vücut kitle indeksi, ejeksiyon fraksiyonu, NYHA sınıfı, önceden KY'den yatış hikayesi, KY'nin süresi, atriyal fibrilasyon, geçirilmiş inme, kreatinin seviyesi, sakubitril/valsartan-enalapril tedavilerine randomizasyon ve log NT-proBNP) göre yapılan ayarlama sonucunda olayların görülme sıklığı aynı idi. Örneğin primer bileşik sonuca göre bakıldığında; iskemik grup ' 1 ' olarak referans alınırsa hipertansif ve idiyopatik gruplar için 'hazardratio (\%95 güven aralığı) ve p-değerleri' sirasiyla $0.87(0.75-1.02), \mathrm{p}=0.082$ ve $0.92(0.82-$

Yazışma adresi: Dr. Mehmet Eren. Sağlık Bilimler Üniversitesi, Dr. Siyami Ersek Göğüs Kalp Damar Cerrahisi Eğitim ve Araşıırma Hastanesi, Kardiyoloji Kliniği, İstanbul, Turkey. Tel: +90 542 - 2626484 e-posta: meseren@hotmail.com 


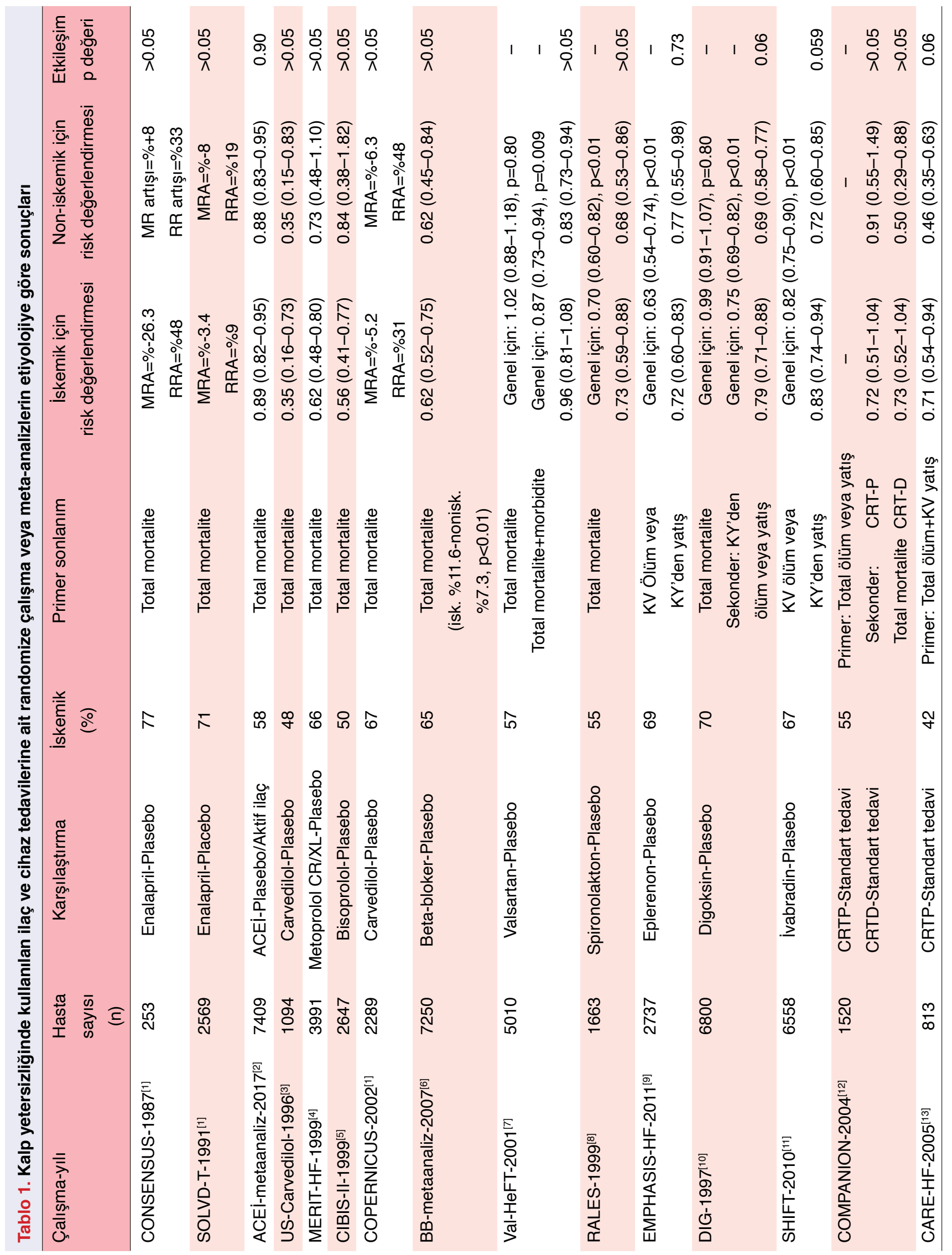




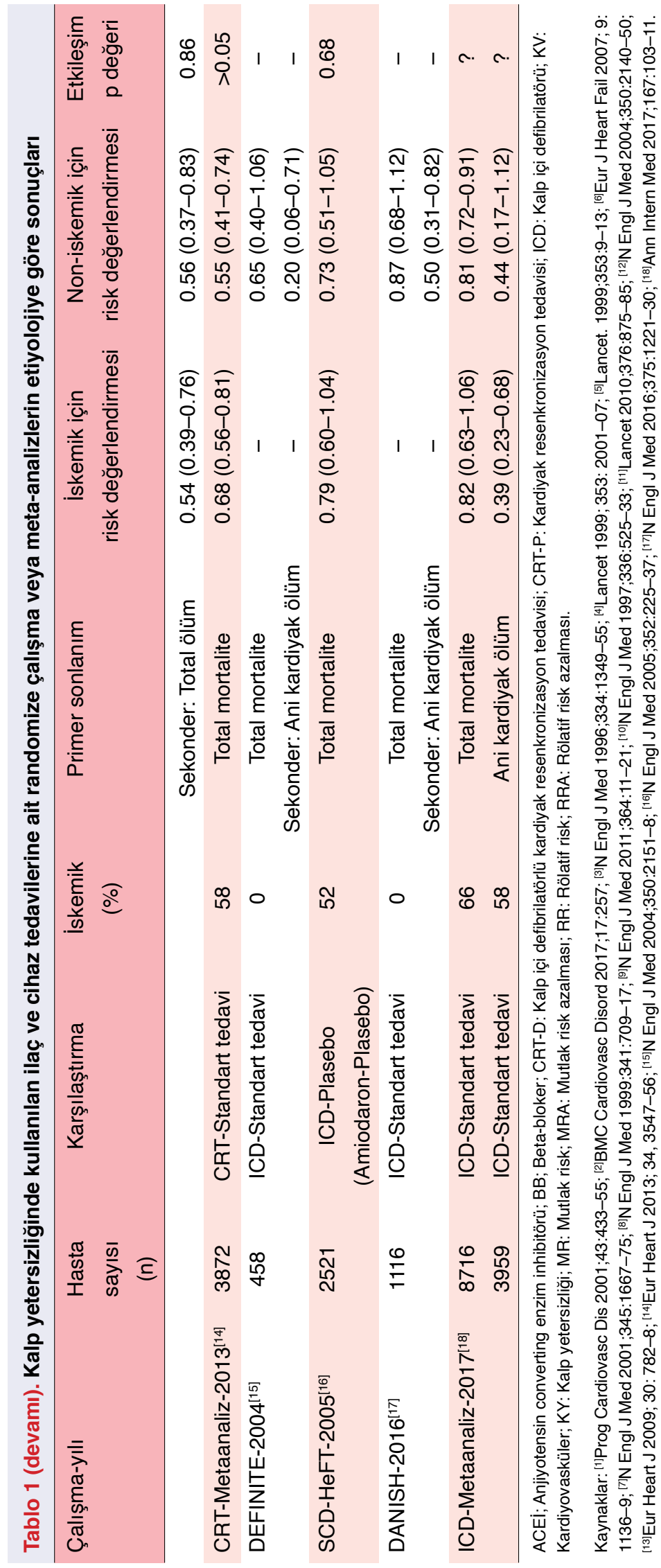

$1.04), p=0.207$ idi. Sakubitril/valsartan tedavisinin enalapril tedavisine göre primer sonucu ve kardiyovasküler ölümü azaltması etiyolojik gruplardan etkilenmemekte idi (sırasıyla etkileşim p değeri 0.11 ve 0.55 ) (Şekil 1).

PARADIGM-HF çalışmasının etiyolojiye göre elde edilen sonuçlarını kliniğe uygularken bazı hususları göz önünde bulundurmak gerekir. İlk olarak PARADIGM-HF çalışmasındaki hastaların çoğunluğu (\%60) iskemik nedene sahipti. New England Journal of Medicine dergisinde 1986-2005 yılları arasında yayınlanmış 24 KY çalışmasının toplam 43568 hastanın \%62'si iskemik kökenli idi. ${ }^{[11]}$ Tablo 1'deki çalışmalara baktığımızda da iskemik hastaların \%42-77 arasında ve ortalama \%61 olduğu görülmektedir. Türkiye'den de hastaların verilerini içeren 'Avrupa Kardiyoloji Derneği Kalp Yetersizliği Uzun Süreli (ESC-HF-LT)' kayıt çalışmasında 7173 kronik KY hastasının \%43'ü iskemik etiyolojiye sahipti. ${ }^{[12]}$ Bildirilen oranlardaki farklılıklar muhtemelen iskemik KY tanımlanmasından kaynaklanıyor olabilir. Genellikle tanımlama; daha önce koroner anjiyografide koroner arter hastalığı bulunması, geçirilmiş miyokard infarktüsü veya koroner revaskülarizasyon hikayesine dayandırılmaktadır. Hastalarda koroner arter hastalığı gözden kaçırılabildiği gibi, bilinen koroner arter hastalığının KY'ye yol açamayacak yaygınlıkta olması da yanlışlıkla iskemik olarak tanımlanabilir. Bu yüzden çalışmaları standardize edebilmek için Tablo 2'de verilen Felker ve ark. ${ }^{[13]}$ önerdiği tanımlamayı kullanmak daha doğru olacaktır.

Çalışma sonuçlarını yorumlamada ikinci husus ise, hastaların prognozunda etyolojinin etkisiz bulunmasidır. PARADIGM-HF çalışmasında iskemik hastalarda istenmeyen olayların daha sık olduğu saptandı. Ancak PARADIGM-HF çalışması etyolojiye göre randomize edilmediği için, iskemik ile noniskemik gruplar arasında prognozu etkileyecek farklılıklar vardı. Bu farklılıklara göre istatistiki ayarlama yapıldığında, her iki grup arasında olayların gelişimi açısından fark görülmedi. Son 10 yıldan önce yapılmış olan meta-analiz veya kayıt çalışmalarında DEF-KY hastalarında iskemik neden mortalitenin bağımsız belirleyicisi iken, ${ }^{[1,2,14]}$ son 10 yılda bildirilen verilerde iskemik nedenin mortaliteye bir etki- 
PARADIGM-HF popūlasyonu kalp yetersizliği etiyolojisine göre; iskemik ( $n=5036)$ ve non-iskemik ( $n=3363$ ) olarak gruplandirildi.

$\checkmark$ LCZ696 $2 \times 200 \mathrm{mg} / \mathrm{gūn}$ tedavisini iskemik=2530 ve non-iskemik=1681 hasta alıyordu. Diğer hastalar da Enalapril $2 \times 20 \mathrm{mg} / \mathrm{gün}$ aliyordu.

\section{$\checkmark$ Primer bileşik sonuç; kardiyovasküler ölüm veya kalp yetersizliğinden yatış idi.}
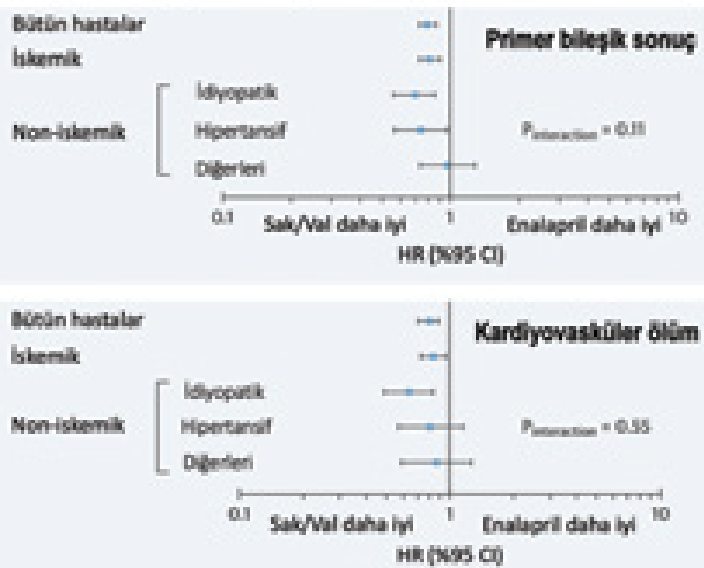

Balmforth C, et al. J Am Coll Cardiol He 2019;7:457-65.

\section{BULGULAR:}

1. Primer bileșik sonuç en fazla iskemik grupta gōrüldū (yilda her 100 hasta için iskemik $=12.31$, Hipertansif $=10.41$ ve idiyopatik=10.95).

2. Bazı değișkenlere gŏre ayarlama yapıldı.̆̆ında gruplar arasında primer sonuç açısından fark gōrülmedil.

3. Sacubitril/valsartan'ın Enalaprile gōre faydası etiyolojik gruplar arasında da tutarlı idi (resim).

SONUÇ: Düşūk ejeksiyon fraksiyonlu kalp yetersizliği hastalarında etiyoloji; ne prognozu ne de sakubitril/valsartan tedavisinin enalaprile göre olan üstünlügünủ değisstirmemektedir.

Şekil 1. PARADIGM-HF çalışmasının etiyolojiye göre sonuçları.

Tablo 2. İskemik KMP'nin tanımı (DEF-KY'de aşağıdakilerden en az bir tanesinin varlığı)

1. Geçirilmiş $M i$ veya koroner revaskülarizasyon (CABG ameliyatı veya $\mathrm{PCI}$ ) hikayesi

2. Sol ana koroner veya $L A D$ proksimalinde $\geq \% 75$ darlık

3. İki veya daha fazla epikardiyal koroner damarda $\geq \% 75$ darlık

CABG: Koroner arter by-pass greftleme ameliyatı; DEF-KY: Düşük ejeksiyon fraksiyonlu kalp yetersizliği; LAD: Sol ön-inen koroner arter; KMP: Kardiyomiyopati; Mi: Miyokard infarktüsü; PCl: Perkütan koroner girişim.

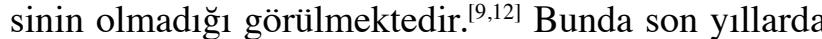
KY için kılavuzlarda önerilen tedavilerin daha yüksek bir oranda hastalar tarafından kullanılıyor olmasının ve revaskülarizasyon tekniklerindeki gelişmelerin payı büyüktür. Ayrıca PARADIGM-HF çalışmasının verileri; daha önceki çalışmalarda olmayan natriüretik peptid gibi daha fazla sayıdaki faktörler için sağlam istatiksel ayarlama yapmaya imkan sağlıyordu.

Çalışmanın diğer çarpıcı bir sonucu da sakubitril/ valsartan tedavisinin enalaprile olan üstünlüğünün etiyolojiden etkilenmemesidir. Günümüzde KY tedavilerinin bireyselleştirilerek daha etkili olunabileceği tartışılmaktadır. Tedavilerinin bireyselleştirilmesinde hastaların fenotipi veya genotipine dayalı veriler kullanılabildiği gibi, tedavinin yönlendirilmesinde bazı belirteçlerin yol gösterici olabileceği hakkında çalışmalar da vardır. Hastaların cinsiyeti, yaşı, fonksiyonel kapasitesi, yetersizliğe yol açan etyoloji, kan basınc1, kalp hızı, böbrek fonksiyonları, biyobelirteçler gibi değişkenler fenotipik özellikleri oluşturmaktadır.
Böylece KY tedavisini yönlendirmede yetersizliğin nedeni yol gösterici olacaktır. Şöyle ki; uygun iskemik hastalarda cerrahi revaskülarizasyon sonuçları düzelttiği gibi, ${ }^{[3]}$ noniskemik hastalarda kalp içi defibrilatörü daha az etkilidir. ${ }^{[4]}$ Bunun yanı sıra; KY tedavisinde kullanılan ivabradinin etkinliği etiyolojiden etkilenmeksizin yüksek kalp hızlarında görülebildiği gibi, ${ }^{[15]}$ nörohormonal mekanizmalara yönelik olan ilaçların etkinliğinin etiyolojiden bağımsız olduğu görülmektedir. Ancak valsartan tedavisinin KY'de etkinliğini araştıran Val-HeFT çalışmasında istatistiki anlamlılığa ulaşmasa da, iskemik hastalarda noniskemiklere göre daha az etkin (sirasıyla mortalite veya morbidite kombinasyonu üzerine standart tedaviye göre $\% 4$ ve \%17 azalma) olduğu görülmektedir. ${ }^{[16]}$ Genel popülasyonda da valsartanın primer sonuçlardan total mortaliteye etkisi görülmedi. Diğer primer sonuç olan total mortalite veya morbidite kombinasyonunda \%13 azalma sağlamakta olup, bu faydanın çoğunluğu da KY yatışlarında yaptığ $1 \% 24$ azalmadan kaynak- 
lanmaktadır. Bütün çalışma popülasyonunda nörohormonal blokerlere göre yapılan alt grup analizlerinde ise, valsartanın ACEİ almayan hastalarda hem mortalite ve hem de morbiditeye etkili olduğu görülmüştür. Val-HeFT'in ilginç bir alt grup analizi ise, hem ACEI ve hem de beta-bloker alan hastalara valsartan verildiğinde olumsuz etkilerinin görülmesidir. Bu çelişkili sonuçlar; Val-HeFT çalışmasının hasta içeriğinin karmaşıklığından ve alt grup analizlerinde de hasta say1larının azlığından kaynaklanmakta idi. PARADIGMHF çalışması ile Val-HeFT'deki KY nedenine göre oluşan şüpheler giderilmiş olup, sakubitril/valsartanın etkinliğinin KY nedeninden etkilenmediği net bir şekilde görülmüştür. $\mathrm{Bu}$ durum $\mathrm{KY}$ 'de nörohormonal mekanizmaların işleyişi ile açıklanabilir. Bilindiği gibi; KY'ye yol açan sebep ne olursa olsun, kalp debisini artırmak için ortak yol nörohormonların aktivasyonudur. Başlangıçta optimal debiyi sağlamaya çalışan nörohormonlar uzun dönemde sol ventrikül dilatasyonuna ve fonksiyon bozukluğuna yol açarlar. Bu yüzden KY'nin gidişatını belirleyen güç yetersizliğe yol açan sebep değil, nörohormonlardır. ${ }^{[17]}$ Böylece nörohormonal mekanizmaya yönelik olan bir ilaç, KY ilerleyişindeki ortak yolu etkilemektedir.

Sonuç olarak; DEF-KY hastalarında etyoloji, ne prognozu ne de sakubitril/valsartan tedavisinin enalaprile olan üstünlügüünü değiştirmemektedir.

\section{Kaynaklar}

1. Frazier CG, Alexander KP, Newby LK, Anderson S, Iverson E, Packer $\mathrm{M}$, et al. Associations of gender and etiology with outcomes in heart failure with systolic dysfunction: a pooled analysis of 5 randomized control trials. J Am Coll Cardiol 2007;49:1450-8.

2. Martínez-Sellés M, Doughty RN, Poppe K, Whalley GA, Earle N, Tribouilloy $\mathrm{C}$, et al. Gender and survival in patients with heart failure: interactions with diabetes and aetiology. Results from the MAGGIC individual patient meta-analysis. Eur J Heart Fail 2012;14:473-9.

3. Velazquez EJ, Lee KL, Jones RH, Al-Khalidi HR, Hill JA, Panza JA, et al. Coronary-Artery Bypass Surgery in Patients with Ischemic Cardiomyopathy. N Engl J Med 2016;374:1511-20.
4. Køber L, Thune JJ, Nielsen JC, Haarbo J, Videbæk L, Korup E, et al. Defibrillator Implantation in Patients with Nonischemic Systolic Heart Failure. N Engl J Med 2016;375:1221-30.

5. Linde C, Abraham WT, Gold MR, Daubert C; REVERSE Study Group. Cardiac resynchronization therapy in asymptomatic or mildly symptomatic heart failure patients in relation to etiology: results from the REVERSE (REsynchronization reVErses Remodeling in Systolic Left vEntricular Dysfunction) study. J Am Coll Cardiol 2010;56:1826-31.

6. Bristow MR, Anderson FL, Port JD, Skerl L, Hershberger RE, Larrabee $\mathrm{P}$, et al. Differences in beta-adrenergic neuroeffector mechanisms in ischemic versus idiopathic dilated cardiomyopathy. Circulation 1991;84:1024-39.

7. Shore S, Aggarwal V, Zolty R. Carvedilol or sustained-release metoprolol for congestive heart failure: a comparative effectiveness analysis. J Card Fail 2012;18:919-24.

8. Colucci WS, Braunwald E. Pathophisiology of heartfailure. In: Zipes DP, Libby P, Bonow RO, Braunwald E, editors. Braunwald's Heart Disease: A Textbook of Cardiovascular Medicine. Phidelphia: Elsevier-Saunders; 2005. p. 509-38.

9. Balmforth C, Simpson J, Shen L, Jhund PS, Lefkowitz M, Rizkala AR, et al. Outcomes and Effect of Treatment According to Etiology in HFrEF: An Analysis of PARADIGM-HF. JACC Heart Fail 2019;7:457-65.

10. McMurray JJ, Packer M, Desai AS, Gong J, Lefkowitz MP, Rizkala $\mathrm{AR}$, et al. Angiotensin-neprilysin inhibition versus enalapril in heart failure. N Engl J Med. 2014;371:993-1004.

11. Gheorghiade M, Sopko G, De Luca L, Velazquez EJ, Parker JD, Binkley PF, et al. Navigating the crossroads of coronary artery disease and heart failure. Circulation 2006;114:1202-13.

12. Crespo-Leiro MG, Anker SD, Maggioni AP, Coats AJ, Filippatos G, Ruschitzka F, et al. European Society of Cardiology Heart Failure Long-Term Registry (ESC-HF-LT): 1-year follow-up outcomes and differences across regions. Eur J Heart Fail 2016;18:613-25.

13. Felker GM, Shaw LK, O'Connor CM. A standardized definition of ischemic cardiomyopathy for use in clinical research. J Am Coll Cardiol 2002;39:210-8.

14. Pecini R, Møller DV, Torp-Pedersen C, Hassager C, Køber L. Heart failure etiology impacts survival of patients with heart failure. Int $\mathbf{J}$ Cardiol 2011;149:211-5.

15. Swedberg K, Komajda M, Böhm M, Borer JS, Ford I, Dubost-Brama A, et al. Ivabradine and outcomes in chronic heart failure (SHIFT): a randomised placebo-controlled study. Lancet 2010;376:875-85.

16. Cohn JN, Tognoni G; Valsartan Heart Failure Trial Investigators. A randomized trial of the angiotensin-receptor blocker valsartan in chronic heart failure. N Engl J Med 2001;345:1667-75.

17. Udelson JE, Stevenson LW. The Future of Heart Failure Diagnosis, Therapy, and Management. Circulation 2016;133:2671-86. 